\title{
Clozapine: a review of clinical practice guidelines and prescribing trends
}

\author{
Stephanie Warnez ${ }^{\dagger}$ and Silvia Alessi-Severini ${ }^{* \dagger}$
}

\begin{abstract}
Background: Clozapine effectiveness in the treatment of refractory schizophrenia has been sustained by published evidence in the last two decades, despite the introduction of safer options.

Discussion: Current clinical practice guidelines have strongly recommended the use of clozapine in treatment-resistant schizophrenia, but prescribing trends do not appear to have followed such recommendations. Clozapine is still underutilized especially in patients at risk of suicide. It seems that physicians are hesitant in prescribing clozapine due to concerns about serious adverse effects. Recent reports have highlighted the need to inform health professionals about the benefits of treating patients with clozapine and have voiced concerns about the underutilization of clozapine especially in patients at risk of suicide.
\end{abstract}

Summary: Guidelines and prescribing patterns reported in various countries worldwide are discussed. Suggestions on how to optimize clozapine utilization have been published but more efforts are needed to properly inform and support prescribers' practices.

Keywords: Clozapine, Prescribing, Schizophrenia, Antipsychotic(s), Utilization, Guidelines

\section{Background}

Clozapine efficacy as an "atypical" antipsychotic agent has been recognized since the early 1960s [1]. This agent became available on the European market for the treatment of schizophrenia with the promise of a better tolerability because of the absence of those extrapyramidal side effects that afflicted patients treated with other antipsychotic agents (e.g., chlorpromazine and haloperidol, now defined as "typical" or first- generation agents, FGAs) [1]. However, the release of alarming reports of agranulocytosis in Finnish patients created panic among prescribers; a total of 17 cases were confirmed among 100 patients treated with clozapine, 8 of those cases resulted in fatalities. Clozapine was immediately withdrawn from the market by Sandoz (1976) [1].

It was not until fourteen years after its withdrawal that the results of the pivotal US Clozaril Study were published and the important role of clozapine in clinical practice was discovered [2]. Clozapine demonstrated superiority to chlorpromazine in treatment-resistant patients in many outcomes including treatment response,

\footnotetext{
* Correspondence: Silvia.Alessi-Severini@umanitoba.ca

${ }^{\dagger}$ Equal contributors

Faculty of Pharmacy, University of Manitoba, Winnipeg, MB, Canada
}

with improvements in positive and negative symptoms of schizophrenia [2]. This led health agencies to grant clozapine access to the US and Canadian markets in 1990 and 1991, respectively.

The recognized risk for agranulocytosis, assessed at a prevalence of $1-2 \%$, has been managed since then by mandatory monitoring systems administered by the manufacturers of the clozapine products (now generized in most countries) to assure that patients undergo routine blood testing before each dispensation. Current product monographs mandate that patients start therapy gradually and that normal WBC and absolute neutrophil counts (ANC) are maintained at safe levels (WBC count $\geq 3500 / \mathrm{mm}^{3}$ and ANC $\geq 2000 / \mathrm{mm}^{3}$ ) throughout treatment [3]. Thus, patients at risk of developing agranulocytosis can be identified before the condition becomes life-threatening. The implementation of registries for the monitoring of hematological toxicity has in fact significantly reduced mortality and morbidity in patients treated with clozapine [4].

The 1990s saw also the introduction of other new "atypical" antipsychotics (e.g., risperidone, olanzapine, quetiapine also identified as second-generation agents, SGAs). These agents, developed to obtain efficacious medications similar to clozapine without the hematological toxicity, 
generated hope for improved compliance and Quality of Life (QoL) in patients affected by schizophrenia. Early studies of SGAs demonstrated superiority over the FGAs, including a lower incidence of EPS, superior efficacy for positive, negative and mood symptoms, improved tolerability, as well as cognitive enhancing effects [5-8]. Despite higher costs, SGAs were widely adopted worldwide [9-12]. However, none of the newer SGAs could demonstrate superiority to clozapine and in the last decade many published clinical practice guidelines [13-20] have recommended that clozapine be prescribed to patients with treatment-resistant schizophrenia, which has been defined as not responsive to two trials of any other antipsychotic medication (either FGA or SGA). Despite such recommendations and the overwhelming evidence of clozapine effectiveness, prescribing of clozapine appears to be low, delayed and often preceded by attempts at polypharmacy treatment, which lacks clinical evidence of effectiveness [21-26].

\section{Aim and scope}

The main objectives of this article are to provide information on clozapine place in therapy and to discuss clozapine's prescribing trends since the publication of the most recent schizophrenia clinical practice guidelines in North America and Europe.

\section{Methods}

Clinical practice guidelines, meta-analyses, and reports on clozapine prescribing trends have been identified from searches in PubMed, Psychinfo, EMBASE and Cochrane databases. The search was focused on publications in the last 10-year period (2004 and 2014). Articles selection was limited to those written in the English language. Individual clinical trials and older landmark studies have been cited where appropriate. Keywords used in the literature search included: clozapine, prescribing, schizophrenia, antipsychotic(s), utilization, guidelines.

\section{Results}

\section{Clozapine vs. FGAs}

Clozapine effectiveness was initially demonstrated against chlorpromazine, the prototype of the FGAs [2]. Evidence of clozapine advantage over FGAs has been well established and results of various trials, conducted mostly in the 1990s, have been included in meta-analyses [27-29]. The conclusions were that clozapine was more effective than FGAs in reducing symptoms of schizophrenia according to measurements of BPRS scores and SANS negative symptoms scores. Clozapine produced clinically meaningful improvements and postponed relapse [30-32].

\section{Clozapine vs. SGAs}

The landmark study CUtLASS 2 found that in patients failing to respond to two or more antipsychotics, clozapine produced significant improvement in symptoms over 1 year [33]. The phase 2E CATIE study revealed that clozapine was significantly more effective than quetiapine and risperidone, and the authors concluded that in patients with an insufficient therapeutic response to a SGA, clozapine was more effective than switching to a different SGA [34-36].

More recent evidence has confirmed clozapine superiority to other SGAs and olanzapine [37,38].

\section{Clozapine effectiveness on mortality}

Effects of clozapine treatment on patient mortality has been assessed and reviewed over the years in various populations. The evidence supports a clear advantage of clozapine therapy in terms of reduced mortality over other antipsychotic agents including FGAs, risperidone and quetiapine [39-42].

\section{Clinical practice guidelines and algorithms}

The evidence produced in the last 20 years, and summarized by published clinical practice guidelines and algorithms, has confirmed clozapine to be the gold standard for treatment-resistant schizophrenia. Please refer to Table 1 for a summary of recommendations.

\section{Clozapine prescribing trends}

Treatment-resistant schizophrenia has been established to affect $20-30 \%$ of all patients diagnosed with schizophrenia [21,31]. Nevertheless, physicians' prescribing practices reveal that only a small portion of patients with treatmentresistant schizophrenia are treated with clozapine [21]. In 1999 , only 160,000 US patients of the 2.6 million diagnosed with schizophrenia were treated with clozapine (only $25 \%$ of treatment-resistant patients) [21]. Since the introduction of the newer SGAs, clozapine use decreased in the United States: in 1999, clozapine represented $11 \%$ out of the total SGAs prescribed, which steadily decreased to less than 5\% in 2002 [21]. During phase 3 of the CATIE study, 51\% of patients had previously discontinued medications due to ineffective therapeutic response, but only $11 \%$ of patients were offered clozapine during phase 3 . Studies of clozapine utilization have shown that adherence to guidelines has been poor through the years with clozapine been consistently underutilized in the US, UK, Canada, New Zealand and Australia [9,21-26,42-46]. In a study of the Veterans Health Administration, only $2 \%$ of patients affected by schizophrenia were receiving clozapine [22].

Adherence to treatment guidelines in the UK was also very poor in terms of clozapine initiation as in more than $34 \%$ of patients' polypharmacy and high dose treatments were used before commencing clozapine [23].

Recent Canadian statistics, based on physician drug recommendations from 2005 to 2009, show a $48 \%$ increase in clozapine recommendations over a 5-year period [10]; however, a more recent report determined 
Table 1 Summary of evidence-based recommendations for clozapine prescribing

\begin{tabular}{|c|c|c|c|c|}
\hline \multirow[t]{2}{*}{ Date } & \multirow[t]{2}{*}{ Source } & \multirow{2}{*}{$\begin{array}{l}\text { Recommendation: clozapine to be } \\
\text { prescribed or offered to patients } \\
\text { After failure of } 2 \text { adequate } \\
\text { trials of } 2 \text { different AAs }\end{array}$} & \multirow[b]{2}{*}{$\begin{array}{l}\text { With suicidal thoughts } \\
\text { or behaviours }\end{array}$} & \multirow[b]{2}{*}{$\begin{array}{l}\text { With persistent hostility anc } \\
\text { violent behaviours }\end{array}$} \\
\hline & & & & \\
\hline 2004 & APA (US) [13] & $\mathrm{x}$ & & \\
\hline 2005 & CPA (CAN) [14] & $\mathrm{x}$ & & \\
\hline 2007 & TMAP (US) [15] & $\mathbf{X}$ (SGAs considered first-line) & & \\
\hline 2009 & NICE (UK) [16] & $\begin{array}{l}\mathbf{X} \text { (at least one of the drugs should } \\
\text { be a non-clozapine SGA) }\end{array}$ & & \\
\hline 2010 & Schizophrenia PORT (US) [17] & $\mathrm{x}$ & $x$ & $x$ \\
\hline 2010 & CADTH [18] & $x$ & & \\
\hline 2011 & BAP (UK) [19] & $\mathrm{x}$ & & $\mathrm{x}$ \\
\hline 2013 & PAP (US) [20] & $\begin{array}{l}\mathbf{X} \text { (SGA, risperidone and olanzapine) } \\
\text { considered first-line) }\end{array}$ & $x$ & $\mathrm{x}$ \\
\hline
\end{tabular}

Note: $\mathrm{AA}=$ antipsychotic agent, $\mathrm{APA}=$ American Psychiatric Association, BAP = British Association for Psychopharmacology, $\mathrm{CADTH}=\mathrm{Canadian}$ Agency for Drugs and Technology in Health, CPA = Canadian Psychiatry Association, PAP = Psychopharmacology Algorithm Project, PORT = Patient Outcomes Research Team, TMPA = Texas Medication Algorithm Project.

that $68 \%$ of an outpatient population had tried 3 or more antipsychotics before switching to clozapine [26]. In contrast, clozapine utilization in Australia appears to be more appropriate with a percentage as high as $51 \%$ of clozapine use in treatment-resistance schizophrenia [46].

\section{Discussion}

Despite the long and still ongoing debate about the comparative safety and effectiveness of FGAs and SGAs $[5,6]$, during the last two decades, clozapine has maintained its place in therapy as the treatment of choice in refractory schizophrenia (third-line agent). It has also been suggested that earlier use (as a second line agent) can be recommended in individuals with persistent hostility/aggressive behaviour [47] and suicidalilty [39-42]. In fact the indication for recurrent suicidal behavior has been officially approved by the FDA [48]. Its role in first-episode and non-treatment-resistant patients has been investigated [49-53] and while further research in the area of early onset schizophrenia and time to treatment response is needed [54-57], clozapine value as a second line agent has been recently recognized in a firstepisode schizophrenia population [58].

While clinical practice guidelines have strongly endorsed clozapine as the gold standard of therapy, its use has been lower that recommended. Reasons for physicians' reluctance to prescribe clozapine have been evaluated and the relatively high incidence of agranulocytosis has certainly had great influence; however, the careful monitoring of WBC counts and ANC has almost completely abolished the risk of fatal agranulocytosis; frequency of blood tests has recently been simplified and once WBC counts and ANCs have been maintained within normal levels for one year, blood tests are now only required once every 4 weeks $[27,47]$. It is also of importance to note that in some European countries a more flexible monitoring schedule, which can be reduced to quarterly blood testing in individuals not at risk, has been proposed $[59,60]$.

Concerns over other adverse effects, which include weight gain, hyperglycemia, seizures, tachycardia, myocarditis and neuromalignant syndrome [61], can affect the decision making process and even less severe side effects (sedation, constipation, nocturnal hypersalivation) might result in patients' resistance to try this medication $[42,62]$. Clozapine has shown, however, a definite advantage in reversing tardive dyskinesia $[13,17,34,58]$. Suggestions on how to balance safety and effectiveness of clozapine have been given [63]. Other issues can be seen in the added costs associated with blood monitoring and health care system contacts due to the need for gradual titration of clozapine therapy, however, clozapine costeffectiveness has been consistently shown over other agents $[64,65]$. Recent reports have highlighted the need to inform health professionals about the benefits of treating patients with clozapine [24,66-69] and have voiced concern that clozapine is still under utilized especially in patients at risk of suicide [66]. Interprofessional practice models that see pharmacists being more involved in patient care have been advocated to improve and optimize prescribing of clozapine [70].

\section{Summary}

- Published clinical evidence has supported clozapine as the gold standard in the treatment of refractory schizophrenia as it is reflected in the recommendations of many clinical practice guidelines.

- Clinical practice guidelines, however, do not appear to have been followed by prescribers and clozapine 
remains an underutilized medication in patients with treatment-resistant schizophrenia.

- Efforts are needed to encourage and optimize clozapine utilization.

\section{Abbreviations}

AA: Antipsychotic agent; ANC: Absolute neutrophil count; APA: American Psychiatric Association; BAP: British Association for Psychopharmacology; BPRS: Brief Psychiatric Rating Scale; CADTH: Canadian Agency for Drugs and Technologies in Health; CPA: Canadian Psychiatry Association; CATIE: Clinical Antipsychotic Trials of Intervention Effectiveness; CUtLASS: Cost Utility of the Latest Antipsychotic Drugs in Schizophrenia Study; EPS: Extrapyramidal Symptoms; FDA: Food and Drug Administration; FGAs: First Generation Antipsychotics; NICE: National Institute of Health and Clinical Excellence; PAP: Psychopharmacology Algorithm Project; PORT: Patient Outcomes Research Team; QoL: Quality of Life; SANS: Scale for the Assessment of Negative Symptoms; SGAs: Second Generation Antipsychotics; TD: Tardive dyskinesia; TMAP: Texas Medication Algorithm Project; WBC: White blood cells.

\section{Competing interests}

The authors declare that they have no competing interests.

\section{Authors' contributions}

SW conducted the bibliographic research and drafted the article. SAS designed and supervised the project, and wrote the final draft. Both authors read and approved the final manuscript.

\section{Acknowledgments}

No financial support was sought for this project.

Received: 5 November 2013 Accepted: 31 March 2014

Published: 7 April 2014

\section{References}

1. Crilly J: The history of clozapine and its emergence in the US market: a review and analysis. Hist Psychiatry 2007, 18(1):39-60.

2. Kane J, Honigfeld G, Singer J, Meltzer $\mathrm{H}$ : Clozapine for the treatment-resistant schizophrenic, A double-blind comparison with chlorpromazine. Arch Gen Psychiatry 1988, 45(9):789-796.

3. Clozaril: Product Monograph. Health Canada http://webprod5.hc-sc.gc.ca/ dpd-bdpp/info.do?code=11421\&lang=eng Accessed on January 30, 2014.

4. Honigfeld G, Arellano F, Sethi J, Bianchini A, Schein J: Reducing clozapinerelated morbidity and mortality: 5 years of experience with the Clozaril National Registry. J Clin Psychiatry 1998, 59(Suppl 3):3-7.

5. Hartling L, Abou-Setta A, Dursum S, Mousavi SS, Pasichnyk D, Newton AS: Antipsychotics in adults with schizophrenia: comparative effectiveness of first-generation versus second-generation medications. Ann Int Med 2012, 157:498-511.

6. Leucht S, Cipriani A, Spinelli L, Mavridis D, Orey D, Richter F, Samara M, Barbui C, Engel RR, Geddes JR, Kissling W, Stapf MP, Lässig B, Salanti G, Davis JM: Comparative efficacy and tolerability of 15 antipsychotic drugs in schizophrenia: a multiple treatments meta-analysis. Lancet 2013, 382:951-962.

7. Leucht S, Pitschel-Walz G, Abraham D, Kissling W: Efficacy and extrapyramidal side-effects of the new antipsychotics olanzapine, quetiapine, risperidone, and sertindole compared to conventional antipsychotics and placebo: a meta-analysis of randomized controlled trials. Schizoph Res 1999, 35:51-68.

8. Correll CU, Leucht S, Kane JM: Lower risk for tardive dyskinesia associated with sec- ond-generation antipsychotics: a systematic review of 1-year studies. Am J Psychiatry 2004, 161:414-425.

9. Alessi-Severini S, Biscontri R, Collins D, Kozyrskyj A, Sareen J, Enns M: Utilization and Costs of Antipsychotic Agents: a Canadian Population-Based Study: 1996-2006. Psychiatr Serv 2008, 59(5):547-553.

10. Pringsheim T, Lam D, Tano DS, Patten SB: The pharmacoepidemiology of antipsychotics for adults with schizophrenia in Canada, 2005 to 2009. Can J Psychiatry 2011, 56(10):630-634.

11. Aparasu RR, Bhatara V, Gupta S: US national trends in the use of antipsychotics during office visits, 1998-2002. Ann Clin Psychiatry 2005, 17:147-152.
12. Trifirò G, Spina E, Brignoli O, Sessa E, Caputi AP, Mazzaglia G: Antipsychotic prescribing pattern among Italian general practitioners: a population- based study during the years 1999-2002. Eur J Clin Pharmacol 2005, 61:47-53.

13. Lehman AF, Lieberman JA, Dixon LB, McGlashan TH, Miller AL, Perkins DO, Kreyenbuhl J, American Psychiatric Association; Steering Committee on Practice Guidelines: Practice guideline for the treatment of patients with schizophrenia, second edition. Am J Psychiatry 2004, 161(2):1-56.

14. Addington D, Bouchard RH, Goldberg J, Honer B, Malla A, Norman R, Tempier R, Berzins S: Clinical practice guidelines: treatment of schizophrenia. Can J Psychiatry 2005, 50(Suppl. 1):7S-57S.

15. Moore TA, Buchanan RW, Buckley PF, Chiles JA, Conley RR, Crismon ML, Essock SM, Finnerty M, Marder SR, Miller DD, McEvoy JP, Robinson DG, Schooler NR, Shon SP, Stroup TS, Miller AL: The Texas Medication Algorithm Project: antipsychotic algorithm for schizophrenia: 2006 update. J Clin Psychiatry 2007, 68:1751-1762.

16. National Institute of Health and Clinical Excellence: Core intervention in the treatment and management of schizophrenia in primary and secondary care (CG82). 2009. http://publications.nice.org.uk/schizophreniacg82 Accessed January 30, 2014.

17. Buchanan RW, Kreyenbuhl J, Kelly DL, Noel JM, Boggs DL, Fischer BA, Himelhoch S, Fang B, Peterson E, Aquino PR, Keller W, Schizophrenia Patient Outcomes Research Team (PORT): The 2009 schizophrenia PORT psychopharmacological treatment recommendations and summary statements. Schizophr Bull 2010, 36(1):71-93.

18. Clozapine Treatment of Hospitalized Patients: A Review of Clinical Practice Guidelines and Safety. Report December 20, 2010 Accessed on August 10, 2012 http://www.cadth.ca/en/search?q=Clozapine+ treatment+in+hospitalized.

19. Barnes TRE, Schizophrenia consensus group of the British Association for Psychopharmacology: Evidence-based guidelines for the pharmacological treatment of schizophrenia: recommendations from the British Association for Psychopharmacology. J Psychopharmacol 2011, 25(5):567-620.

20. Osser DN, Roudsari MJ, Manschreck T: The psychopharmacology algorithm project at the Harvard South Shore Program: an update on schizophrenia. Harv Rev Psychiatry 2013, 21(1):18-40.

21. Moore TA, Covell NH, Essock SM, Miller AL: Real-world antipsychotic treatment practices. Psychiatr Clin North Am 2007, 30(3):401-416.

22. Taylor DM, Young C, Paton C: Prior antipsychotic prescribing in patients currently receiving clozapine: a case note review. J Clin Psychiatry 2003, 64:30-34.

23. Wheeler AJ: Treatment pathway and patterns of clozapine prescribing for schizophrenia in New Zealand. Ann Pharmacother 2008, 42:852-860.

24. Joober R, Boksa P: Clozapine: a distinct, poorly understood and underused molecule. J Psychiatry Neurosci 2010, 35(3):147-159.

25. Howes OD, Vergunst F, Gee S, McGuire P, Kapur S, Taylor D: Adherence to treatment to guidelines in clinical practice: study of antipsychotic treatment prior to clozapine initiation. BJP 2012, 201:481-485.

26. Alessi-Severini S, LeDorze JA, Nguyen D, Honcharik P, Eleff M: Clozapine prescribing in a Canadian outpatient population. Plos One 2013, 8(12):e83539.

27. Breier A, Buchanan RW, Kirkpatrick B, Davis OR, Irish D, Summerfelt A, Carpenter WT Jr: Effect of clozapine on positive and negative symptoms in outpatients with schizophrenia. Am J Psychiatry 1994, 151:20-26.

28. Essock SM, Hargreaves WA, Covell NH, Goethe J: Clozapine's effectiveness for patients in state hospitals: results from a randomized trial. Psychopharmacol Bull 1996, 32:683-697.

29. Rosenheck R, Cramer J, Xu W, Thomas J, Henderson W, Frisman L, Fye C, Charney D: Comparison of clozapine and haloperidol in hospitalized patients with refractory schizophrenia. N Engl J Med 1997, 337:809-815.

30. Chakos M, Lieberman JA, Hoffman E, Bradford D, Sheitman B: Effectiveness of second-generation antipsychotics in patients with treatment-resistant schizophrenia: a review and meta-analysis of randomized trials. Am J Psychiatry 2001, 158:518-526.

31. Leucht S, Corves C, Arbter D, Engel RR, Li C, Davis JM: Second-generation versus first-generation antipsychotic drugs for schizophrenia: a meta-analysis. Lancet 2009, 373(9657):31-41.

32. Essali A, Al-Haj HN, Li C, Rathbone J: Clozapine versus typical neuroleptic medications for schizophrenia. Cochrane Database Syst Rev 2010, 20(1):CD000059. pub2.

33. Lewis SW, Barnes TR, Davies L, Murray RM, Dunn G, Hayhurst KP, Markwick A, Lloyd H, Jones PB: Randomized controlled trial of effect of prescription of 
clozapine versus other second-generation antipsychotic drugs in resistant schizophrenia. Schizophr Bull 2006, 32(4):715-723.

34. Lieberman JA, Stroup S, McEvoy JP, Swartz MS, Rosenheck RA, Perkins DO, Keefe RS, Davis SM, Davis CE, Lebowitz BD, Severe J, Hsiao JK, Clinical Antipsychotic Trials of Intervention Effectiveness (CATIE) Investigators: Effectiveness of antipsychotic drugs in patients with chronic schizophrenia. N Engl J Med 2005, 353:1209-1223.

35. Stroup TS, Lieberman JA, McEvoy JP, Davis SM, Swartz MS, Keefe RS, Miller AL, Rosenheck RA, Hsiao JK, CATIE Investigators: Results of phase 3 of the CATIE schizophrenia trial. Schizophr Res 2009, 107(1):1-12.

36. McEvoy JP, Lieberman JA, Stroup TS, Davis SM, Meltzer HY, Rosenheck RA, Swartz MS, Perkins DO, Keefe RS, Davis CE, Severe J, Hsiao JK, CATIE Investigators: Effectiveness of clozapine versus olanzapine, quetipine, and risperidone in patients with chronic schizophrenia who did not respond to prior atypical antipsychotic treatment. Am J Psychiatry 2006, 163:600-610.

37. Asenjo Lobos C, Komossa K, Rummel-Kluge C, Hunger H, Schmid F, Schwarz S, Leucht S: Clozapine versus other atypical antipsychotics for schizophrenia. Cochrane Database Syst Rev 2010, (11):CD006633.

38. Souza JS, Kayo M, Tassel I, Martins CB, Elkis H: Efficacy of olanzapine in comparison with clozapine for treatment-resistant schizophrenia: evidence from systematic review and meta-analyses. CNS Spectrums 2013, 18(2):82-89.

39. Duggan A, Wagner J, Knapp M, Kerwin R: Modelling the impact of clozapine on suicide in patients with treatment-resistant schizophrenia. BJP 2003, 182:505-508.

40. Tiihonen J, Lönnqvist J, Wahlbeck K, Klaukka T, Niskanen L, Tanskanen A Haukka J: 11-year follow up of mortality in patients with schizophrenia: a population-based cohort study (FIN 11 study). Lancet 2009, 374:620-627.

41. Kasckow J, Felmet K, Zisook S: Managing suicide risk in patients with schizophrenia. CNS Drugs 2011, 25(2):129-143

42. Wasserman D, Rihmer Z, Rujescu D, Sarchiapone M, Sokolowski M, Titelman D, Zalsman G, Zemishlany Z, Carli V, European Psychiatric Association: The European Psychiatric Association (EPA) guidance on suicide treatment and prevention. Eur Psychiatry 2012, 27:129-141.

43. Conley RB, Kelly DL, Lambert TJ, Love RC: Comparison of clozapine use in Maryland and in Victoria, Australia. Psychiatr Serv 2005, 56:320-323.

44. Goren JL, Meterko M, Williams S, Young GJ, Baker E, Chou CH, Kilbourne AM, Bauer MS: Antipsychotic prescribing pathways, polypharmacy, and clozapine use in treatment of schizophrenia. Psychiatr Serv 2013, 64(6):527-533

45. Latimer E, Wynant W, Clark R, Malla A, Moodie E, Tamblyn R, Naidu A: Underprescribing of clozapine and unexplained variations in use across hospitals and regions in the Canadian province of Quebec. Clin Schizophr Relat Psychoses 2013, 7(1):33-41.

46. Malalagama G, Bastiampillai T, Dhillon R: Clozapine use in Australia. Australas Psychiatry 2011, 19(2):175.

47. Frogley C, Taylor D, Dickens G, Picchioni M: A systematic review of the evidence of clozapine's anti-aggressive effects. Int J Neuropsychopharmacol 2012, 15:1351-1371.

48. "Clozaril" Prescribing information http://www.accessdata.fda.gov/drugsatfda_ docs/label/2013/019758s069s071 lbl.pdf Accessed January 30, 2014

49. Woerner MG, Robinson DG, Alvir JM, Sheitman BB, Lieberman JA, Kane JM: Clozapine as a first treatment for schizophrenia. Am J Psychiatry 2003, 160(8):1514-1526.

50. Lieberman JA, Phillips M, Gu H, Stroup S, Zhang P, Kong L, Ji Z, Koch G, Hamer RM: Atypical and conventional antipsychotic drugs in treatment-naïve first-episode schizophrenia: a 52-week randomized trial of clozapine vs chlorpromazine. Neuropsychopharmacology 2003, 28(5):995-1003.

51. Agid O, Remington G, Kapur S, Arenovich T, Zipursky RB: Early use of clozapine for poorly responding first-episode psychosis. J Clin Psychopharmacol 2007, 27(4):369-373.

52. Swartz MS, Perkins DO, Stroup TS, Davis SM, Capuano G, Rosenheck RA, Reimherr F, McGee MF, Keefe RS, McEvoy JP, Hsiao JK, Lieberman JA, CATIE Investigators: Effects of antipsychotic medications on psychosocial functioning in patients with chronic schizophrenia: findings from the NIMH CATIE study. Am J Psychiatry 2007, 164(3):428-436

53. Meltzer HY, Bobo WV, Lee MA, Cola P, Jayathilake K: A randomized trial comparing clozapine and typical neuroleptic drugs in non-treatment-resistant schizophrenia. Psychiatry Res 2010, 177(3):286-293.
54. Ascher-Svanum H, Nyhuis AW, Faries DE, Kinon BJ, Baker RW, Shekhar A: Clinical, functional, and economic ramifications of early nonresponse to antipsychotics in the naturalistic treatment of schizophrenia. Schizophr Bull 2008, 34(6):1163-1171.

55. Chang YC, Lane HY, Yang KH, Huang CL: Optimizing early prediction for antipsychotic response in schizophrenia. J Clin Psychopharmacol 2006, 26(6):554-559.

56. Correll CU, Malhotra AK, Kaushik S, McMeniman M, Kane JM: Early prediction of antipsychotic response in schizophrenia. Am J Psychiatry 2003, 160(11):2063-2065. Erratum in: Am J Psychiatry 2005, 162(9):1774.

57. Gallego JA, Robinson DG, Sevy SM, Napolitano B, McCormack J, Lesser ML, Kane JM: Time to treatment-response in first -episode schizophrenia: should acute treatment trials last several months? J Clin Psychiatry 2011, 72:1691-1696

58. Agid O, Arenovich T, Sajeev G, Kipursky RB, Kapur S, Foussias G, Remington $\mathrm{G}$ : An algorithm-based approach to first-episode schizophrenia: response rates over 3 prospective antipsychotic trials with a retrospective data analysis. J Clin Psychiatry 2011, 72(11):1439-1444.

59. Netherlands Clozapine Collaboration Group: Guideline for the use of clozapine [English version]. 2009. [Cited 14 July 2010] http:// clozapinepluswerkgroep.nl/pdf/SKMBT_C45110040808460.pdf.

60. Schulte PF, Cohen D, Bogers JPAM, van Dijk D, Bakker B: A Dutch guideline for the use of clozapine. Aust N Z J Psychiatry 2010, 44:1055-1056.

61. Van-Kammen DP, Marder SR: Serotonin/dopamine antagonists. In Comprehensive Textbook of Psychiatry. 7th edition. Edited by Kaplan $\mathrm{HI}$, Sadock BJ. Baltimore, Md: Lippincott Williams \& Wilkins; 2000:2455-2473.

62. Hermes E, Resenheck: Choice of randomization to clozapine versus other second-generation antipsycotics in the CATIE schizophrenia trial. J Psychopharmacol 2012, 26:1194-1200.

63. Meltzer HY: Clozapine: balancing safety with superior antipsychotic efficacy. Clin Schizophr Relat Psychoses 2012, 6(3):134-144.

64. Phanthunane $P$, Vos T, Whitefors $H$, Bertram M: Cost-effectiveness of pharmacological and psychosocial interventions for schizophrenia. Cost Eff Resour Alloc 2011, 9:6. doi:10.1186/1478-7547-9-6.

65. Attard A, Taylor DM: Comparative Effectiveness of Atypical Antipsychotics in Schizophrenia. CNS Drugs 2012, 26(6):491-508.

66. Sinyor M, Remington G: Is psychiatry ignoring suicide? J Clin Psychopharmacol 2012, 32(3):307-308.

67. Hill M, Freudenreich O: Clozapine: key discussion points for prescribers. Clin Schizophr Relat Psychoses 2013, 6(4):177-185.

68. Damkier NJ, Taylor LH: Optimizing clozapine treatment. Acta Psychiatric Scand 2011, 123:411-422.

69. Beck K, Howes O: Optimising treatment of refractory schizophrenia. Psychopharmacology 2013, 227:373-374

70. Williams T, Purvis TL: Development of an outpatient pharmacist-managed clozapine clinic. Am J Health-Syst Pharm 2012, 69:1192-1195.

doi:10.1186/1471-244X-14-102

Cite this article as: Warnez and Alessi-Severini: Clozapine: a review of clinical practice guidelines and prescribing trends. BMC Psychiatry 2014 14:102

\section{Submit your next manuscript to BioMed Central and take full advantage of:}

- Convenient online submission

- Thorough peer review

- No space constraints or color figure charges

- Immediate publication on acceptance

- Inclusion in PubMed, CAS, Scopus and Google Scholar

- Research which is freely available for redistribution 